\title{
PROBLEMATIKA PENDIDIKAN PONDOK PESANTREN DI ERA GLOBALISASI
}

\author{
Ja'far \\ Dosen STAI AL-YASINI Pasuruan \\ sbgjakfar86@mail.com
}

\begin{abstract}
ABSTRAK
Pesantren sejatinya adalah tempat penyiaran Agama dan pendidikan tertua di Indonesia walaupun sekarang kepercayaan masarakat sudah mulai berkurang .dan untuk mempertahan kiprah pesantren di zaman modern ini pesantren harus melakukan perubahan dalam menghadapi kemajuan zaman.

Untuk mewujudkan hal di atas memang tidak mudah. Akan tetapi dimana ada kemauan pasti adajalan. Salah satu usaha pondok pesantren dalam menghadapi era globalisai dan kemajuan teknologi ialah dengan menggunakan sistem terpadu yaitu dengan memadukan pendidikan Agama, pendidikan Umum, meberikan keterampilan-keterampilan dan pelatihan agar lulusannya siap pakai dan mandiri juga mempunyai bekal untuk menghadapi kehidupan dunia dan ahirat.
\end{abstract}

Kata kunci; Problematika, Pendidikan Pondok Pesantren, Globalisasi

\section{PENDAHULUAN}

Pondok pesantren sebagai lembaga dan sentral perkembangan pendidikan agama Islam, lahir dan berkembang dari masa ke masa, semenjak permulaan kedatangan agama Islam di Indonesia ini.

Pelaksanan pendidikan di Indonesia merupakan tanggung jawab seluruh komponen bangsa. Dalam prakteknya masarakat ikutserta mencerdaskan kehidupan bangsa ini, tidak hanya dari segi materi dan moril, namun juga telah memberikan sumbangsih yang siknifikan dalam penyelenggaraan pendidikan. Dalam hal ini dengan banyak bermunculannya lembaga suwasta yang merupakan bentuk dari penyelenggaraan pendidikan masarakat termasuk lembaga luar sekolah yang didirikan masrakat adalah pondok pesantren. Pondok pesantren merupakan lembaga pendidikan keagamaan yang tumbuh dan meluas dimasarakat. ${ }^{1}$

Di dalam keberadaan pesantren yang mendapat respon positif

\footnotetext{
${ }^{1}$ Departemen Agama RI,Pola pegembangan pondok pesantren (Jakarta:2003),h.1
} 
dari masyarakat dan sekitarnya karena pesantren mampu memberikan nilai tambah di lingkungan masarakat, ini terbukti pesantren telah banyak melahirkan manusia-manusia beriman, berilmu dan mampu merubah perilaku dan mental.

Upaya-upaya pembaharuan telah banyak dilakukan dari waktu ke waktu untuk menunjukkan keberadada serata peran dan pengembangan dalam menghadapi problematikanya. ${ }^{2}$

Sebagaimana diketahui, bahwa globalisasi meniscayakan terjadinya perubahan di segala aspek kehidupan, termasuk perubahan orientasi, persepsi, dan tingkat selektifitas masyarakat Indonesia terhadap pendidikan. Termasuk pesantren, persaingan global juga harus di kedepankan jangan hanya siswa yang penting bisa mengaji dan baca kitab kuning dan lain sebagainya. Bukan berarti seperti, itu dalam mewaspadai industrialisasi tetapi antara ilmu agama dan ilmu umum harus bisa diseimbangkan.

Sejak berdirinya pondok pesantren pada abad yang sama dengan masuknya islam hingga sekarang. Pesantren telah bergumul dengan masarakat luas.Pesantren telah berpengalaman dengan berbagai corak masarakat dalam rentang waktu itu dan pesantren tumbuh berkembang atas dukungan mereka. Sementara fungsi pesantren pada awal berdirnya hingga sekarang telah mengalami banyak perubaha. Visi, persepsi, dan posisinya terhadap dunia luar telah mengalami perubahan. Laporan Syarif dkk. yang dikutip Mujamil Qomar menyebutkan bahwa pesantren pada masa paling awal (masa Maulan Malik Ibrahim) befungsi sebagai tempat sentral pendidika dan penyiaran agama Islam. Kedua fungsi ini bergerak saling menopang. Pendidikan dapat dijadikan bekal untuk menyampaikan dakwah sedangkan dakwah dapat digunakan sebagai sarana dalam membangun sistem pedidikan. ${ }^{3}$

Fungsi pesantren sebagai lembaga pendidikan tidak lepas dari tujuan berdirinya pesantren itu sendiri yaitu untuk mencerdaskan kehidupan bangsa. Pada awalnya pendidikan pesantren menggunakan sistem trodisonal, sistem ini sangat sederhana contohnya seperti sorogan, watona dan bandongan lebih maju lagai sistem pendidikan pesantren menggunakan sistem modern karena sistem yang lama dianggap kurang sesuai dengan perkembangan zaman maka perlu

${ }^{2}$ Rucman basori, The founding father pesantren modern Indonesia jejak langkah K.H.A.Wahid Hasim (Jakarta: Inceis,2006 ), hal.34

${ }^{3}$ Mujamil Qomar, pesantren dari tranformasi demokratis intuisi (PT. Glora aksara),h.22

351 I PROBLEMATIKA PENDIDIKAN PONDOK PESANTREN DI ERA GLOBALISASI 
adanya inovasi di samping sistem tradisional sebagai ciri khas pesantren. Inovasi yang dilakukan dengan cara membuka sekolah-sekolah, kursus dan pelatihan keterampilan bagi para santri dengan tujuan agar para santri berdaya dalam menghadapi, modrenisasi,industrialisasi dan globalisasi.

Dengan adanya pengetahuan modern, industri,hasil teknologi dan kebudayaan yang dibawa orang asing akan sangat berpengaruh baik positif maupun negatif terhadap kehidupan bagai badai yang takdapat dihindari lagi. ${ }^{4}$

Hal itu bukan suatu hal yang mustahil bakal terjadi. Perkembangan teknologi dan informasi yang disertai dengan nilai-nilai budaya Barat pada akhirnya akan mengikis nilai-nilai Islam yang sudah mengakar di masyarakat. Sebagaimana pengalaman dampak globalisai. Sementara budaya negatif semakin dominan dengan merajalelanya perjudian, minuman-keras (alkohol), dan prostitusi. Dampaknya masyarakat setempat tidak punya cukup kekuatan untuk menolak masuknya budaya luar bercitra negatif dalam komunitas mereka dan secara lambat laun akan mengubah tradisi-tradisi setempat yang Islami, ke tradisi-tradisi yang lebih mengarah pada budaya asing. Bisa jadi nantinya, masyarakat pasuruan yang biasanya sesudah shalat maghrib mengaji Al-Qur'an dan wiridan, setelah mengalami industrialisasi melakukan aktivitas entertainment yang jauh dari nilai-nilai Islami.

Pesantren yang menjadi harapan masrakat dan tempat menuntut ilmu bagi masarakat dengan harapan mampu menghadapi permasalahan yang ada, ternyata pesantren itu sendiri juga menghadapi problem adapun permasalahan yang dihadapi pondok pesantren yaitu:

a. Problem kurikulum karena kebanya pesntren terutama yang salaf kurikulumnya masih tetap menggunakn kurikulum tradisional sehingga lulusannya maksimal guru ngaji atau pencceramah sebagian ada yang jadi petani dan jadi pengangguran. $^{5}$

b. Manajemen dan perencanaannya, banyak pesantren yang tanpa menggunakan manajemen dan perencanaan pokoknya yang penting jalan sehingga pesatren ini tidak ada perkembangan dan kemajuan.

c. Keuwangan. Keuangan pesantren dihasikan dari iuran santri sementra kebanyakan santri nya dari ekonomi rendah dan iuran nya disesuaikan dengan kemampuan akibat untuk

${ }^{4}$ H. Zainal Abidin Ahmad, Memperkembangkan dan mempertahan pendidikan islam di Indonesia, (Jakarta:1976), hal 76

${ }^{5}$ Imam Bawani. Op.Cit,h.56 
biyaya operasionalnya serinng kekurngan.

d. Kesiswaan karena kebanyakan santrinya berasal dari pelosokdesaan dan bermatapencahariannya pertanian, ketika musim panen tiba wali santri meminta ijin untuk meliburkan anaknya agar dapat membantunya tapi seiring dengan perkembangan wali santri sudah mulai menerima perubahan. ${ }^{6}$

Menyadari kompleksitas masalah yang dihadapi mengharuskan pondok pesantren untuk berbenah diri mencari alternatif solusinya mengadakan pembaharuan serta pengembangan dalam semua aspek pendidikan, sebab kalau tidak eksistensi pondok pesantren akan terisolasi dari dunia pendidikan.

\section{KAJIAN PUSTAKA}

\section{A. Kajian tentang Pondok Pesantren}

\section{Pengertian Pondok Pesantren}

Pondok pesantren adalah kata majmuk yang terdiri dari dua kata yaitu pondok dan pesantren. Keduanya mempunyai pengertian yang saling melengkapi.Walaupun ada yang membedakan kedua istilah tersebu, akan tetapi kebanyakan dari mereka menganggapnya sama saja.

Hasjim Munif dalam bukunya yang berjudul pondok pesantren berjuang dalam kancah kemerdekaan dan pembangunan pedesaan mengatakan bahwa istilah pondok barangkali berasl dari pengertian asrama-asrama para murid, yang disebut pondok atau asrama santri yang terbuat dari bambu atau dari bahasa Arab dengan kata funduk yang berarti hotel atau asrama. ${ }^{7}$

Sedangkan istilah pesantren secara etimologi berasal dari kata santri dengan awalan "pe" dan akhiran"an" berati asrama santri para santri. Dapat pula istilah pesantren diambil dari kata sant (manusia baik),kemudian di hubungkan dengan kata tran (suka menolong) sehingga kata pesantren dapat diartikan dengan 'tempat pendidikan manusia yang baik-baik. ${ }^{8}$

Menurt Johns dan C.C Berg seperti yang dikutip H.Banbun

${ }^{6}$ Departemen Agama RI,Pola pengembangan masarakat melalui pondok pesantren (2003),h.58

${ }^{7}$ Moh. Hasjim Munif. pondok pesantren berjuang dalam kancah kemerdekaan dan pembangunan pedesaan (Surabaya: Sinar jaya, 1992), h. 6

${ }^{8}$ H.khorul Huda Basyir,Lc.dkk.Potret Dakwah NU, (Jakarta: PPLDU, 2006), h. 152

353 I PROBLEMATIKA PENDIDIKAN PONDOK PESANTREN DI ERA GLOBALISASI 
Suharto sebagai berikut.

. Johns berpendapat bahwa istilah santri berasal dari bahasa Tamil yang berarti guru mengaji. Sedangkan C.C. Berg berpendapat bahwa istilah "shantri" dalam bahasa India berarti orang yang tahu buku-buku suci agama Hindu, atau seorang sarjana ahli kitab agama Hindu. Kata shantri berasal dari kata shastra yang menunjukana arti buku suci, buku agama atau buku tentang ilmu pengetahuan. ${ }^{9}$

Menurut Imam Bawani maudikatakan pondok, pesantren atau pondok pesantren intinya adalah sebuah komplek atau lembaga pendidikan di situ ada seorang kyai sebagai pengasuh atau pemimpin utamanya dan ada santri yang belajar serta tinggal di kawasan tersebut sebagaimana yang ada sekarang ini. ${ }^{10}$

Dengan pengertian lain, bahwa pesantren merupakan suatu tempat yang di dalamnya terdapat kegiatan belajar mengajar tentang agama Islam. Sedangkan pondok hanya sebagai penginapan, jadi bersifat umum.

Menelaah dari pendapat para pakar tersebut, kami simpulkan bahwa kata pondok dan pesantren itu jelas merupakan dua kata yang identik yaitu asrama tempat santri atau tempat murid belajar mengaji.

Pengertian semacam itu bila dihadapkan pada realitas sosial dunia pesantren pada saat ini sudah tidak ada relevansinya lagi, karena perubahan yang terjadi di luar pesantren secara tidak langsung juga harus diikuti oleh dunia pesantren jika tetap ingin eksis dalam kehidupan masyarakat.

Dalam hal ini Dawam Raharjo menyatakan seperti yang dikutip Hasjim Munif bahwa pesantren adalah sebuah lembaga pendidikan dan dakwah agama Islam, itu adalah pesantren pada awal perkembangannya sekarang telah terjadi perubahan dalam pandngan masyarakat, sebagai akibat dari pengaruh globalisai. Definisi di atas tidak memadai, walaupun pada intinya pesantren tetap pada fungsinya yang asli yang selalu terjaga di tengah-tengah arus perubahan yang tidak bisa dibendunglagi. Bahkan karena menyadari kecepatan perubahan yang sering kali tidak bisa terkendali pihak luar justru memperhatikan keunikannya sebagai wilayah sosial yang mengandung kekuatan resestensi terhadap dampak modernisasi. ${ }^{11}$

Di dalam dunia pesantren terdapat suatu kecenderungan

${ }^{9}$ H. Babun Suharto, Dari pesantren untuk ummat, (Surabaya: Imtiyaz, 2011), h. 19

$10 \quad$ Imam Bawani. Op.Cit, h. 161

${ }^{11}$ Hasjim Munif, Op.Cit, h. 6 
untuk mengembangkan fungsi pesantren, yaitu bukan saja sebagai lembaga agama, melainkan juga sebagai lembaga pendidikan dan sosial. Tugas yang digarap bukan saja soal-soal agama, tetapi juga menanggapi persoalan ke masyarakat dan mencarikan jalan keluar persoalan-persoalan masyaraka, seperti mengatasi kemiskinan, memelihara tali persaudaraan, memberantas pengangguran, kebodohan, dan menciptakan kehidupan yang sehat dan sebagainya.

Keberadaan pondok pesantren dan masyarakat merupakan dua sisi yang tidak dapat dipisahkan, karena keduanya saling mempengaruhi sebagian besar pesantren berkembang dari adanya dukungan masyarakat dan secara sederhana muncul atau berdirinya pesantren merupakan inisiatif masyarakat secara individu maupun kolektif. Begitu pula sebaliknya perubahan sosial dalam masyarakat merupakan dinamika yang dihadapi pondok pesantren dalam pendidikan dan dalam mengembangkan masyarakat.

Menurut Kuntowijojo seperti yang dikutip oleh Bahari Ghazali pondok pesantren melakukanperubah selalu berupya sebagai lembaga pendidikan yang bergerak di bidang pendidikan dan sosial. Berangkat dari beberapa pengertian tentang pondok pesantren tersebut, maka dapat kami simpulkan, bahwa pondok pesantren adalah suatu lembaga pendidikan Islam atau tempat (asrama) yang terorganisir sebagai tempat belajar santri. ${ }^{12}$

Sedangkan menurut Abd. Muin $M$ dkk pesantren yang mampu mengembangkan dua potensinya yaitu potensi pendidikan dan kemasarakatan diharapkan tidak hanya melahirkan kiai yang berwawasan luas tetapi jugak harus mampu beradabtasi dengan derasnya perubahan. ${ }^{13}$

Dari berbagai pendapat di atas dapat kami simpulkan, bahwa pondok pesantren adalah lembaga pendidikan Islam yang di dalamnya menyelenggarakan pendidikan formal maupun nonformal. Bahkan tidak lepas dari itu pondok pesantren adalah tempat mencetak generasi Islam, hingga menjadi generasi yang berguna bagi bangsa dan negara terutama bagi agama dalam menjalankan sunnatullah.

${ }^{12}$ M. Bahari Ghazali, Pesantren berwawasan lingkungan, (Jakarta: CV prasasti, 2003), h. 13

${ }^{13}$ Abd. Muin M dkk, Pengembangan ekonomi pesantren, (Jakarta: CV prasasti,2007), h. 23 


\section{Karakteristik Pondok Pesantren}

Pondok pesantren sebagai lembaga pendidikan Islam berbeda dengan pendidikan lainnya baik dari aspek sistem pendidikan maupun unsur pendidikan yang dimilikinya. Perpaduan dari sistem pendidikannya, terlihat dari proses belajar mengajarnya yang cenderung kesederhanaan dan tradisional, sekalipun juga terdapat pesantren yang bersifat memadukannya dengan sistem pendidikan Islam modern. Yang mencolok dari perbedaan itu merupakan unsur-unsur dominan dalam keberadaan pondok pesantren. Bahkan unsur-unsur dominan itu merupakan ciri-ciri (karakteristik) khusus pondok pesantren.

Ada beberapa tanda yang secara jelas dimiliki pondok pesantren sebagai lembaga pendidikan sekaligus sebagai lembaga sosial yang memberikan dukungan dalam pengembangan masyarakat. Zamakhsyari Dhofir seperti yang dikutip Moh Hsjim Munif mengatakan ada lima bagian pondok pesantren yang melekat atas dirinya yang meliputi: pondok, masjid, pengajaran kitab-kitab kuno, santri dan kyai. ${ }^{14}$

Pondok pesantren bukan hanya terbatas dengan kegiatankegiatan pendidikan keagamaan melainkan mengembangkan diri menjadi suatu lembaga pengembangan masyarakat. Oleh karena itu pondok pesantren sejak semula merupakan ajang mempersiapkan kader masa depan.

a. Masjid

Masjid merupakan elemen penting yang tidak dapat dipisahkan dengan pesantren dan dianggap tempat yang paling tepat untuk mendidik santri terutama dalam melakukan praktek sholat/sembahyang lima waktu, khutbah, sholat jum'at, dan pengajaran kitab-kitab klasik (kitab kuning). Sejak zaman nabi, masjid telah mejadi pusat pendidikan islam. Di manapun kaum muslimin berada, mereka selalu menggunakan masjid sebagai tempat pertemuan, tempat pendidikan, aktivitas administrasi dan cultural. ${ }^{15}$

Di di pesantren masjid dijadikan ajang atau sentral kegiatan pendidikan Islam baik dalam pengertian modern maupun tradisional. Dalam konteks yang lebih jauh masjidlah yang menjadi pesantren pertama, juga dikatakan masjid identik dengan pesantren. Zamakhsyari Dhofir seperti yang dikutip Moh

${ }^{14}$ Moh Hasjim Munif, Op.Cit, h. 7

15 Zuhairi dkk, Sejarah pendidikan islam, (Jakarta: Bumi Aksara, 2008), h. 35 
Hsjim Munif mengatakan seorang kyai yang membangun sebuah pesantren biasanya pertama kali akan mendirikan masjid di dekat rumahnya. ${ }^{16}$

Adapun fungsi masjid di samping menjadi salah satu lembaga pendidikam dan wawasan (tempat) pelaksanaan ibadah juga sebagai tempat latihan seperti muhawaroh, qiro'ah, dan membaca kitab yang ditulis oleh para ulama abad 15 (pertengahan) yang dikenal sebagai kitab kuning yang merupakan salah satu ciri pesantren. ${ }^{17}$

Dari berbagai pendapat di atas kami simpulkan bahwa masjid adalah tempat untuk ibadah, pendidikan, dakwah dan awal si'ar-si'ar Islam dipublikasikan di masa Nabi Muhammad SAW, sebab masjid merupakan lembaga persatuan dan kesatuan umat Islam.

b. Pondok

Setiap pesantren pada umumnya memiliki pondokan. Pondok dalam pesantren pada dasarnya merupakan dua lembaga yang sering penyebutannya tidak dipisah menjadi "pondok pesantren" yang berarti keberadaan pondok dalam pesantren merupakan wawasan pengembangan, pembinaan dan pendidikan serta pengajaran ilmu pengetahuan.

Kedudukan pondok pesantren bagi para santri sangatlah mendasar karena di dalamnya santri tinggal belajar dan di tempat diri pribadinya dengan control seorang ketua asrama atau kiai yang memimpin pesantren itu. Begitu pula melalui pondok kepandaian berbahasa Arab dan Inggris juga mampu menghafal Al-Qur'an begitu pula keterampilan yang lain.

Pondok sebagai wadah pendidikan manusia seutuhnya sebagai operasionalisasi dari pendidikan yakni mendidik dan mengajar, mendidik secara berkeluarga berlangsung di pondok sedangkan mengajarnya di kelas dan Musholla. Hal ini merupakan fase pembinaan dan meningkatkan kualitas manusia sehingga ia bisa tampil sebagai kader masa depan. Menurut Moh.Hasjim Munif pondok atau asrama bagi para santri merupakan ciri khas kebiasaan pesantren, yang membedakannya dengan sistem tradisional di masjid-masjid yang berkembang di

${ }^{16}$ Moh. Hasjim Munif , Op.Cit, h. 49

${ }^{17}$ Amir Daine Indrakusuma, Pengantar ilmu pendidikan, (Surabaya:usaha nasional.). h. 104

357 I PROBLEMATIKA PENDIDIKAN PONDOK PESANTREN DI ERA GLOBALISASI 
kebanyakan wilayah Islam di Negara-negara lain. Bahkan sistem asrama ini pula yang menjadi perbedaan pesantren dengan pendidikan langgar di kawasan Minangkabau. ${ }^{18}$

Oleh karena itu dapat kami simpulkan bahwa pondok pesantren merupakan lembaga pendidikan yang pertama mengembangkan lingkungan hidup dalam arti kata pengembangan sumber daya manusia dari segi mentalnya.

c. Kyai

Ciri yang paling esensial bagi suatu pesantren adalah seorang kyai. Kyai pada hakikatnya adalah gelar yang diberikan kepada seseorang yang mempunyai ilmu di bidang agama dalam hal ini agama Islam terlepas dari anggapan kyai sebagai gelar yang sacral, maka sebutan kyai muncul di dunia pondok pesantren. Dan kyai merupakan Sosok pemimpim yang karismtik.

Wahjosumidjo memberikan ciri-ciri pemimpin karismatik yaitu; bawahan menaruh kepercayaan penuh pada pemimpinnya,ada kesamaan keyakinan, menerima perintah tanpa persoalan,terdapat rasa kasih sayang, keptuhan penuh dan adanya keyakinan bahwa sang pemimpin akan memberikan bantuan untuk keberhasilan kelompok,sedangkan seorang kyai adalah orang yang sangat erat kaitannya dengan suatu pondok pesantren. ${ }^{19}$

Keberadaan kyai dalam pesantren sangat erat sekali. Suatu lembaga pendidikan Islam disebut pesantren apabila memiliki tokoh sentral yang disebut kyai. Jadi kyai di dalam dunia pesantren sebagai penggerak dalam mengemban, mengembangkan dan mengambil keputusan penting untuk kemajuan pesantren.

George R.Terry dalam bukunya yang diterjemah J.Smith D.F.M meyebutkan bahwa mengambil keputusan adalah memilih dari dua plihan atau dari beberapa pilihan yang ada untuk menentukan arah tujuan yang ingin dicapai; Sehingga pesantren sesuai dengan pola yang dikehendaki oleh seorang kyai, dengan tujuan untuk memajukan pesantren. ${ }^{20}$

Menurut Mujammil Qomar kyai adalah pemimpin nonfomal sekaligus pemimpin sepiritual, dan posisinya sangat

Moh. Hasjim Munif, Op.Cit, h. 21

19 Wahjosumijo.Kepemimpinan kepala sekolah Tinjauan teoritik dan permasalahannya, (Jakarta: Rajawali pers, 1995), h. 34

${ }^{20}$ George R.Terry.Trjmah. J.Smith D.F.M. prinsip-prinsip manajemen (Jakarta:Bumi aksara,1993), h. 34 
dekat dengan kelompok-kelompok masarakat lapisan bawah di desa-desa .Sebagai pemimpin masarakat, kyai memiliki jamaah, masa dan nasehat-nasehatnya selalu dipehatikan dan di ikuti. ${ }^{21}$

Dari pendapat di atas dapat kami simpulkan bahwa kyai adalah orang yang berilmu dan mempunyai kharisma, pengambil kebijakan dan sebagai panutan masyarakat.

Zamakhsyari Dhofir seperti yang dikutip Moh Hasjim Munif menjelaskan bahwa asal usul perkataan kyai dalam bahasa Jawa dikoleksi untuk tiga jenis yang berbeda, yaitu:

1) Sebagai nama kemulyaan bagi orang-orang dan benda yang dianggap kelebihan, umpamanya "kyai garuda kencana" digunakan untuk sebutan kereta lawas yang ada di Keraton Jogjakarta.

2) Nama kehormatan untuk orang-orang tua pada umumnya.

3) Nama yang diberikan oleh masyarakat kepada seorang mempuni tetang agama Islam yang memiliki atau menjadi pemimpin pesantren dan mengajar kitab-kitab Islam kuno kepada para santri. Selain gelar kyai ia juga sering disebut seorang alim (tafaqquh fi ddin). ${ }^{22}$

Dengan demikian, kemajuan dan kemunduran pondok pesantren benar-benar terletak pada kemampuan kyai dalam mengatur operasional / pelaksanaan pendidikan di dalam pesantren. Sebab kyai merupakan "penguasa" baik dalam fisik maupun non fisik yang bertanggung jawab bagi kemajuan pesantren lebih jauh pengaruh seorang kyai bukan hanya terbatas dalam pesantrennya, juga memiliki pengaruh terhadap lingkungan masyarakatnya bahkan terdengar ke seluruh penjuru nusantara.

d. Santri

Istilah santri hanya terdapat di pesantren sebagai pengenalan (akhlak) adanya pesertadidik yang butuh akan ilmu pengetahuan yang dimiliki seorang kyai yang memimpin sebuah pesantren. Oleh karena itu santri pada dasarnya berkaitan erat dengan keberadaan kyai dan pesantren.

Menurut Abdul Qodir djaelani. Santri adalah sekelompok orang yang tidak bias dipisahkan dari kehidupan

${ }^{21}$ Mujammil Qomar.Pesantren dari trn formasi metodelogi demokratis intuisi (Glora aksara), h. 29

${ }^{22}$ Hasjim Munif, OpCit.h. 7

359 I PROBLEMATIKA PENDIDIKAN PONDOK PESANTREN DI ERA GLOBALISASI 
ulama. Karena berbicara kehidupan ulama senantiasa menyankut pula kehidupan santri yang menjadi murid dan sekaligus menjdi pengikut setia. Santri yang didik di dalam kawasan pondok pesantren. ${ }^{23}$

Zamakhsyari Dhofir seperti yang dikutip oleh Moh. Hasjim Munif mengatakan santri dibagi menjadi dua kelompok :

1 Santri mukim

Santri mukim santri yang tidak pulang. Tinggal bersama kyai dan secara efektif menuntut ilmu dari seorang kyai. Dapat juga secara langsung sebagai pengurus pesantren yang ikut serata dalam mengurusi santri lain setiap santri yang tinggal telah lama menetap dalam pesantren secara tidak langsung bertindak sebagai wakil kyai. ${ }^{24}$

Menurut M. Bahari Ghozali ada dua tujuan seorang santri menetap sebagai santri mukim :

a) tujuan menuntut ilmu artinya santri itu datang dengan maksud untuk memperdalam pengetauan agama dari kyainya.

b) tujuan menyempunakan ahklak, artinya seorang santri belajar langsung kepada kiainya agar santri tersebut memiliki akhlak yang baik sesuai dengan akhlak kyainya setelah belajar di pesantren. ${ }^{25}$

Jadi penulis simpulkan bahwa santri mukim adalah santri yang menuntut ilmu, tinggal di pesantren dengan keinginan merubah perilaku yang tidak baik hingga menjadi baik.

2 Santri kalong.

Menurt Zamakhsyari Dhofir seperti yang dikutip oleh Moh. Hasjim Munif santri kalong yaitu murid-murid berasal dari desa-desa di sekeliling pesantren yang biasanya tidak menetap dalam pesantren, untuk mengikuti

pelajaran di pesantren mereka bolak-balik atau pulang pergi dari rumahnya sendiri alasan santri yang pergi dan menetap di sebuah pesantren karena berbagai alasan di antaranya:

a) la ingin meningkatkan penegtahuan dari sumber-sumber yang lain yang membahas Islam secara mendalam di

23 Abdul Qodir Djaelani, Peran ulama dan santr dalam pejuangan politik islam di Indonesia, (Surabaya: PT.bina ilmu,1994), h. 7

24 Moh. Hasjim Munif .Op.Cit, hal.13

25 M.Bahari Ghazali, Op.Cit h. 23 
bawah bimbingan kyai yang memimpin pesantren tersebut.

b) la ingin merasakan kehidupan pesantren baik yang berkitan dengan pendidikan, maupun belajar keorganisasian sekligus menjalin hubungan dengan pesantren-pesantren yang terkenal.

c) Memfokuskan studinya di pesantren tanpa ia melupakan kewajiban sehari-hari di rumah keluarganya.

Dari beberapa alasan tersebut di atas, dapat ditarik suatu kesimpulan, bahwa pada dasarnya alasan mereka yaitu ingin memperdalam ilmu baik itu ilmu agama maupun ilmu yang lain agar bermanfaat apabila sudah kembali ke kampung. ${ }^{26}$

e. Pengajaran kitab klasikal

Kitab-kitab Islam klasikal biasanya dikenal dengan istilah kitab kuning. Menurut Martin Van Bruinesen seperti yang dikutip oleh Amin Haidari dkk kitab kuning merupakan ciri dan identitas yang tidak bisa dipisakan dari pesantren. Sebagai lembaga kajian dan pengembangan ilmu-ilmu keislamam(al- 'uluma al-syar' iyah), pesantren menjadikan kitab kuning adalah indentitas yang inheren dengan pesatren. ${ }^{27}$

Babun Suharto menyebutkan bahwa kitab kuning merupakan kitab yang ditulis ulama-ulama pada abat pertengahan, akan tetapi sudah banyak kitab-kitab yang ditulis ulama kontemporer, yang tidak ada harokatnya. Orang juga biasa menyebut dengan kitab gundul. Perlu disampai bahwa tren kitab kuning ini telah mengalami pergeseran makna. Dulu kitab kuning selalu berasosiasi dengan kitab-kitab klasik, tapi kini meliputi kitab-kitab karangan ulama kontemporer. ${ }^{28}$

Adapun tujuan utama pengajaran kitab-kitab klasik untuk mendidik calon-calon ulama. Terka dang ada pondok romadon yaitu santri yang tinggal di pesantren dengan jangka waktu sebulan ketika bulan romadon saja dengan tujuan agar dapat menambah pengtahuan agama dan memperbayak ibdah, antara lain sembahyang sunnaht, membaca Al-quran dan

${ }^{26}$ Moh. Hasjim Munif, Loc, Cit.h. 7

${ }^{27}$ Amin haedari dkk, Masa depan pesantren dalam tantangan modernitas dan kompleksitas global, (Jakarta: IRD Prees, 2004), h. 148

${ }^{28}$ H. Babun Suharto, Op.Cit, h. 120

361 I PROBLEMATIKA PENDIDIKAN PONDOK PESANTREN DI ERA GLOBALISASI 
mengikuti pengajian. $^{29}$

Dari beberapa wacana diatas dapat kami simpulkan bahwa kitab kuning merupakan ciri khas pesatren, karya ulama abad pertengahan, dan kontemporer dengan tujuan pengajaran utuk mencetak kader-kader Islam.

\section{Tujuan pondok pesantren}

Mendirikan pondok pesantren dapat diartikan dengan wahana pendidikan. Sebagai lembaga pendidikan mempunyai tujuan yang akan dicapai. Mastuki dkk menyebutkan tentang tujuan pesantren yaitu mengupayakan terbentuknya muslim yang kafah, berahlak mulia, bermamfaat bagimasarakat, mandiri, bebas dan teguh dalam kepripbadian, menyebarkan agma atau menegakkan agama islam dan keyakinan umat islam di tengah-tengah masarakat ( 'izzul islam walmuslimin), dan mencintai ilmu sesuai keadaan Indonesia. ${ }^{30}$ Sesuai dengan peraturan pemerintah republik Indonesia nomor 55 tentang pendidikan Agama dan keagamaan yang tercantum dalam bab tiga pasal delapan alenia dua sebagai berikut; pendidikan keagamaan bertujuan agar santri bisa memperdalam pengetahuan agamnya, mempertebal keimnannya dan mengamalkan nilai-nilai ajaran agamanya atau menjadi ahli ilmu agama yang berwawasan luas, kritis, kreatif, inovatif, dan dinamis dalam rangka mencerdaskan kehidupan bangsa yang beriman, bertakwa, dan berakhlak mulia. $^{31}$

Lebih jelas lagi, perumusan tujua dari pondok pesantren sebagaimana dari hasil keputusan dalam musyawarah atau lokakarya intensifikasi pengembangan pondok pesantren yang diselenggarakan pada tanggal 9 Juni 1978 di Jakarta, seperti yang dikutip oleh Mujamil Qomar yaitu; ada dua tujuan, tujuan umum dan khusus.

Sedangkan tujuan umum pondok pesantren adalah membina warga agar ber kepribadian muslim sesuai dengan ajaran-ajarana agama Islam dan menanamkan rasa keagamaan tersebut pada segi kehidupannya serta mengupayakan agar santri mampu memaikan peran dilingkungannya, masyarakat dan negaranya.

Sedangkan tujuan khusus dapat dijabarkan sebagai berikut: (a) mendidik siswa atau santri, anggota masyarakat untuk menjadi

\footnotetext{
${ }^{29}$ Moh. Hasjim Munif, Op.Cit, hal.16

${ }^{30}$ Mastuki dkk, manajemen pendidikan pesantren, (Jakarta: DIVA pustaka, 2005), h. 92-93

${ }^{31}$ Departemen pendidikan nasional, peraturan pemerintah republik Indonesia tentang pendidikan agma dan keagamaan, (departemen pendidikan nasional tahun,2007), h: 7
} 
seorang muslim yang bertaqwa kepada Allah dan memiliki kecerdasan, keterampilan dan sehat lahir batin sebagai warga Indonesia yang ber-Pancasila. (b) mendidik siswa/santri untuk menjadikan manusia muslim tabah, tangguh wiraswasta dalam mengembangkan syari' at Islam secara utuh dan dinamis. (c) mendidik santri agar mempunyai kepribadian yang bai dan mencinatai tanah airanya. (d) mendidik tenaga-tenaga penyuluh pembangunan mikro (keluarga) dan regional (pedesaan masyarakat lingkungannya). (e) mendidik siswa atau santri agar menjadi tenaga-tenaga yang cakap dalam berbagai sektor pembangunan, mental spiritual. (f) mendidik siswa atau santri untuk meningkatkan kesejahteraan sosial masyarakat lingkungan dalam rangka usaha pembangunan masyarakat bangsa. ${ }^{32}$

Berdasarkan tujuan yang telah dirumuskan, maka tujuan pendidikan pondok pesantren tidak semata-mata bersifat keagamaan yang berorientasi akhirat. Tetapi mempunyai relefansi dengan kehidupan nyata yang berkembang dalam masyarakat.

\section{Fungsi Pondok Pesantren}

Pondok pesantren memiliki bebagai fungsi yang unik misalkan di jamamn penjajah bah sapai sekrang tetap eksis mekipun dengan bentuk yang sangat sederhana. Oleh karena itu perkembangan masyarakat sekitarnya tentang pemahaman keagamaan (Islam) lebih jauh mengarah pada nilai-nilai normatif, edukatif, progresif.

Nilai-nilai normatif pada dasarnya meliputi kemampuan masyarakat dalam mengerti dan mendalami ajaran-ajaran Islam dalam arti ibadah mahdah sehingga masyarakat menyadari akan pelaksanaan ajaran agama yang selama ini dipupuk. Nilai-nilai pendidikan meliputi pengetahuan dan pemahaman masyarakat muslim secara menyeluruh dapat dikategorikan terbatas, baik dalam masalah agama maupun ilmu pengetahuan pada umumnya. Sedangkan nilai-nilai progresif yang dimaksud adalah adanya kemampuan masyarakat dalam memahami perubahan zaman seiring dengan adanya tingkat perkembangan ilmu dan teknologi. Dalam hal ini masyarakat sangat terbatas dalam masalah perubahan itu sehubungan dengan arus perkembangan desa ke kota. Oleh karena itu adanya perubahan di pesatren memang sesuai harapan

\footnotetext{
${ }^{32}$ Mujammil Qomar, Op. Cit, hal. 2

363 I PROBLEMATIKA PENDIDIKAN PONDOK PESANTREN DI ERA GLOBALISASI
} 
masyarakatnya, sesuai dengan hakikat pondok pesantren cenderung menyatu dengan masyarakat desa. ${ }^{33}$

Sesuai dengan tujuan pondok pesantren yang sedemikian rupa maka pesantren memiliki fungsi sebagai berikut;

a. Pesantren sebagai lembaga pendidikan

Berawal dari bentuk pengajaran yang sangat sederhana, pada akhirnya pesantren berkembang menjadi lembaga pendidikan formal yang diikuti oleh masyarakat, dalam pengertian materi pelajaran secara material maupun imaterial, yakni mengajarkannya bacaan kita-kitab kuning. Titik tekan pola pendidikan semacam itu adalah diharapkan setiap santri mampu menghatamkan kitab-kitab kuning sesuai dengan tingkat yang dihadapkan, sedangkan pendidikan dalam pengertian immaterial cenderung berbentuk suatu upaya perubahan sikap santri, agar santri menjadi seorang pribadi yang kuat dalam kehidupan sehari-hari. ${ }^{34}$

Pemahaman fungsi pondok pesantren sebagai lembaga pendidikan terletak pada persiapan pesantren dalam menyiapkan diri ikut serta dalam pembangunan di bidang pendidikan dengan jalan adanya perubahan sistem pendidikan sesuai dengan arus perkembangan zaman dan erat tekhnologi secara global. Oleh karena itu pula kedudukan pesantren benarbenar sebagai patner yang insentif dalam mengembangkan pendidikan yang dibuktikan dengan makin luasnya pendidikan pesantren seantero dunia.

b. Pondok pesantren sebagai lembaga dakwah

Pengertian sebagai lembaga dakwah terus melihat kiprah pesantren dalam melakukan dakwah di kalangan masyarakat dalam arti melakukan suatu aktivitas menumbuhkan kesadaran beragama atau melaksanakan ajaran-ajaran agama secara konsekuen sebagai pemeluk agama Islam.

Sebenarnya secara mendasar seluruh gerakan pondok pesantren baik di dalam maupun di luar pondok pesantren merupakan langkah-langkah da'wah, sebab pada hakekatnya berdrinya pondok pesantren tidak lepas dari tujuan agama secara total.

Oleh karena itu kehadiran pondok pesantren sebenarnya dalam rangka dakwah Islamiyah juga kegiatan-kegiatan pesantren dapat dikatakan sangat beragam dalam memberikan

\footnotetext{
${ }^{33}$ M. Bahri Ghozali, Op.Cit, h. 35
}

${ }^{34}$ Ibid, h. 36 
pelayanan untuk masyarakat.

c. Pondok pesantren sebagais lembaga sosial

Fungsi pondok pesantren sebagai lembaga sosial menunjukkan keterlibatan pesantren dalam menangani masalahmasalah sosial yang dihadapi oleh masyarakat atau dapat juga dikatakan bahwa pesantren bukan saja sebagai lembaga pendidikan dan dakwah tetapi lebih jauh dari pada itu ada kiprah yang besar dari pesantren yang telah disajikan oleh pesantren untuk masyarakatnya.

Pengertian masalah-masalah sosial yang dimaksud oleh pesantren pada dasarnya bukan saja terbatas pada aspek duniawi melainkan tercakup didalamnya masalah-masalah kehidupan ukhrawi, yang berupa bimbingan rohani yang menurut Sudjoko prasojdo seperti yang dikutip Bahari Ghazli merupakan jasa besar pesantren terhadap masyarakat desa.

1) Kegiatan Tablig kepada masyarakat yang dilakukan dalam kompleks pesantren.

2) Majlis ta'lim atau pengajaran yang bersifat pendidikan kepada umum.

3) Bimbingan hikmah berupa wejangan kyai pada orang yang datang untuk diberi amalan-amalan apa saja yang harus dilakukan untuk mencapai suatu hajat, nasehat-nasehat agama dan sebagainya. ${ }^{35}$

Ketiga kegiatan di atas sasaran pokoknya adalah masyarakat sekitarnya karena itu cenderung sebagai kegiatan sosial keagamaan yang dapat dimasukkan dalam dakwah tetapi juga sebagai fungsi sosial karena intinya adalah supaya membangkitkan semangat untuk hidup lebih layak sesuai dengan ketentuan agama Islam.

Posisi pesantren dalam gerakan sosial sangat dominan di bidang penggarapan manusianya. Hal ini erat hubungannya dengan ciri-ciri pondok pesantren sebagaimana dikemukakan pada keterangan terdahulu.

Keluasan doktrin Islam, menyebabkan semakin menyebarnya pondok pesantren sebagai lembaga sosial terutama di kalangan kelompok pondok kholaf (modern) karena menerima perubahan sesuai dengan tuntutan zaman. Dan kemajuan tingkat berpikir masyarakat mempengaruhi adanya

${ }^{35}$ Ibid, h. 39-40

365 I PROBLEMATIKA PENDIDIKAN PONDOK PESANTREN DI ERA GLOBALISASI 
pengembangan pesantren sebagai lembaga sosial yang cenderung mengangkat harkat manusia.

\section{Sistem pendidikan dan pengajran pondok pesantren}

Pola pendidikan pengajaran pondok pesantren erat kaitannya dengan tepologi pesantren sebagai mana dituangkan dalam karakteristik pondok pesantren. Berangkat dari beberapa pondok pesantren yang ada, maka ada beberapa sistem pendidikan dan pengajaran pondok pesantren:

a. Sistem yang bersifat tradisional

Menurut Sukamto sistem tradisional adalah menggunakan kurkulum diniah yaitu Sembilan puluh persen mengajarkan pelajaran agama, sedangkan untuk bacaan wajib nya adalah kitab klasik, dengan huruf Arab tanpa harokat dan lulusannya mendapatkan ijazah yang tidak diakui oleh perintah apabila mereka ingin melanjutkan ke jejang yang lebih tinggi makaharus mengikuti ujian persamaan terlebih dahulu. ${ }^{36}$

Sistem tradisional adalah sistem yang sangat sederhana diantranya yaitu :

1. Sorogan

Sorogan denga cara santri membaca dihadapan kyai bila ada salahnya lansung diingatkan. ${ }^{37}$

2. Watonan

Menurut mukti ali seperti yag dikutip Bahari Ghazali yaitu: watonan denagan cara kyai membaca dan santri membawa kitab yang sama dan mnyimaknya. ${ }^{38}$

Kedua sistem itu digunanakan pada santri yang sudah mampu membaca dengan lancar dan mengusai al quran.seorang santri mendatangi seorang guru yang akan membacakan beberapa kitab berbahas Arab kemudian diterjemah kedalam bahasa jawa. ${ }^{39}$

3. Bandongan

Zamakhsayri seperti yang dikutip Bahari Ghazali yaitu dengan dirangkai antra sorogan dan watonan dalam system ini seorang santri tidak harus menunjuk tentnag

${ }^{36}$ Sukamto,Kepemimpinan kyai dalam pesan tren, (Jakarta: PT.LP3ES, 1999), h. 139

${ }^{37}$ M. Bahari Ghozali, Op.Cit, h. 29

${ }^{38}$ Ibid, h. 29

${ }^{39}$ Amin haedari dkk , Op.Cit, h. 41 
pelajaran yang ia hadapi. Para kyai dan santri biasnya menerjemah kata-kata yang tidak mampu. ${ }^{40}$

b. Sistem yang besifat modern

1) Klasik, penerapannya ialah dengan mendirikan sekolahsekolah

2) kursus-kursus, penerapannya adalah dengan jalan kursus (takhasusu)

3) Pelatihan, disamping pengajaran klasik dan kursuskursus, dilaksanakan juga pelatihan untuk melatih psikomotorik. $^{41}$

\section{Analisis Data}

Berdasarkan pemaparan data di atas, pada tahapan ini datadata tersebut dianlisis.

Sistem pendidikan merupakan suatu hal yang sangat penting dalam pencapaian tujuan pendidikan mempermudah guru dalam melakukan pembelajaran dan mempermudah santri atau siswa mendapat ilmu yang diinginkan, untuk mencapainya, maka dibutuhkan sistem pendidikan yang sesuai dengan perkembangan zaman dan sesuai dengan karakteristik pesantren.

Sistem pendidikan yang ada di pondok pesantren adalah sistem terpadu yaitu suatu sistem pendidikan pesantren yang memadukan atau menjalankan dua sistem yaitu tradisional dan modern yang ada dalam naungan pondok pesantren walaupun berbeda pelaksanaan waktunya misalnya sistem tradisional dilakukan pada malam hari seperti ngaji kitab dengan cara sorogan, bandongan dan watonan, sementara sistem modern dilaksanakan pada pagi dan siang hari, pagi menggunakan sistem sekolah formal (kurikulum nasioanal) dan ditambah dengan pelatihan-pelatihan, kalau siang menggunakan sistem sekolah yang menggunakan kurikulum pesantren semuaitu merupakan satu kesatuan sistem pondok pesantren.

Pada dasarnya semua pondok pesantren adalah lembaga pendidikan yang selalu berusaha agar santri-santrinya bermanfaat bagi bangsa, negra dan agama, sementara usaha pondok

${ }^{40}$ M. Bahri Ghozali, Op.Cit, h. 30

${ }^{41}$ Ibid h. 30

367 I PROBLEMATIKA PENDIDIKAN PONDOK PESANTREN DI ERA GLOBALISASI 
pesantren dalam menghadapi industrialisasi ialah dengan cara memantapkan pendidikan agama santri-santrinya sebagai pedoman hidup agar tidak terombang-ambing dengan perkembangan zaman, membuka pendidikan formal (pendidikan yang menggunakan kurikulum pemerintah) yang berstandar nasional dan juga dengan mengadakan pelatihan-pelatihan seperti pertanian perindutrian dan lain-lain agar lulusannya sudah siap pakai dan mandiri.

\section{Pembahasan/Interpretasi}

Dengan adanya sistem yang terpadu antara tradisional, modern dan usaha pondok pesantren dengan mengadakan pelatihanpelatihan, maka pondok pesantren mampu menghadapi tantangan zaman dan kemampuan alumninya sesuai dengan harapan masyarakat yang diharapkan mampu menghadapi industrialisasi dengan bekal keterampilan yang diberikan selama sekolah dan mondok di pesantren dengan ijazah yang sudah diakui pemerintah maka tidak mustahil pesantren dan lulusannya mampu bersaing di masyaratkat dalam menghadapi globalisasi.

\section{Kesimpulan}

Sistem pendidikan pondok pesantren menggunakan sisitem terpadu yaitu sistem tradisional dan modern guna untu prsiapan santri untuk menghadapi globalisasi .

a. Sistem tradisiona seperti sorogan, watonan dan bandonga.

b. Sistem modern seperti (membuka sekolah-sekolah baik formal maupun nonformal) dan pelatihan-pelatihan.

Usaha dan upaya pondok pesatren dalam menghadap globalisasi.

a. Memberikan pendidikan agama untuk memantapkan keimanannya agar dengan imannya senantiasa bertakwa pada tuhan.

b. Mengadakan pendidikan umum atau yang berstandar nasional dengan adanya pendidikan ini diharapkan lulusan mempunyai bekal dalam menghadapi industrialisasi.

c. Memberikan pelatihan pertanian yang disesuaikan dengan kebutuhan masarakat sekitar dan pelatihan kerja agar lulusan siap pakai dan mandiri.

\section{Saran-saran}

Kepada pengasuh, pengurus dan guru diharapkan lebih meningkatkan kualitas, profesionalitas dan selalu melakukan perubahan kearah yang lebih baik agar kepercayaan masarakat semakin meningkat terhadap pondok pesantr

Kepada siswa agar selalu memacu semangat dalam belajar serta mengeluarkan daya kreatifitas yang ada pada dirinya, berusaha 
jangan menyerah dan jangan berhenti untuk mencari ilmu guna membangun kemampuan berfikir kreatif dan inovatif menuju perubahan zaman.

\section{DAFTAR RUJUKAN}

Ahmad, Zainal Abidin. 1976. Memperkembangkan dan mempertahankan penddidikan islam di indonesia. Jakarta:

Basir, khorul huda. dkk. 2006. Potret dakwah NU. Jakarta: PPLDU.

Basori, Rucman. 2006. The founding father pesantren modern indonesia jejak langkah KH. A. Wahid Hasim. Jakarta:Inceis.

Bawani, Imam. 1987. Segi-segi pendidikan agama islam Indonesia. Jakarta:

Departemen Agama RI. 2003. Pola pengembangan masarakat melalui pondok pesantren.

Departemen Agama RI. 2003. Pola pengembangan pondok pesantren. Jakarta:

Departemen pendidikan nasional. 2007. Peraturan pemerintah republik indonesia. tentang pendidikan agama dan keagamaan.

Djailani, Abd Qodir.1994. peran Ulama dan santri dalam perjuangan politik Islam di indonesia. Surabaya: PT. Bina ilmu.

Ghazali, Bahari. 2003. Pesantren berwawasan lingkungan. Jakarta: CV. Prasasti.

Haedari, Amin. dkk. 2004. Masadepan pesantren dalam tantangan modernitas dan kompleksitas Global. Jakartas: IRD. Prees.

http://ekoarianto.studens.uii.ac.id/2009/03/25/dampak-industrialisasi-diindonesia akses:24 mei 2011.

http://organisasi.org/pengertian definisi macam jenis dan pengelolaan industri di indonesia perek.akses:24 mei 2011.

http://cessee.com/search/pertumbuhan-industri-alas-kaki-indonesia akses:24 mei 2011.

Kusuma, Amir Daine Indra. Pengantar ilmu pendidikan. Surabaya: Usaha nasional.

M, Abd Muin. dkk. 2007. Pengembanga ekonomi Pesantren. Jakarta: CV. Prasasti.

Mastuki, dkk.2005. Manajemmen pendidikan pesantren. Jakarta: DIVA. Pustaka.

Munif,Moh Hasim. 1992. Pondok pesantren berjuang dalam kancah kemerdekaan dan pembangunan pesdesaan. Surabaya: Sinarjaya. 
Partanto, pius A. dan M dahlan albarri. 1994. Kamus ilmiah populer. Surabaya: Arkola.

Qomar, Mujamil. Pesantren dari tranformasi demokrasi intuisi. PT. Glora aksara..

Suharto, Babun. 2011. Dari pesantren untuk ummat. Surabaya: Imtiyaz..

Sukanto. 1999. Kepemimpinan kyai dalam pesantren.

Sumijo, Wahjo. 1995. Kepemimpinan kepala sekolah tinjauan teoritik dan permasalahannya. Jakrta: Rajawali pers.

Teri, george R. Terjema. J. Smith DFM. 1993. Prinsip manajemen. Jakarta: Bumi aksara.

Timpenyusun pedoman penulisan karya ilmiah Vniversitas negri malang 2007.

Zuhairi, dkk. 2008. Sejarah pendidikan islam. Jakarta: Bumi aksara. 